\title{
A Comparative Analysis of Racial Discrimination in Claude McKay's Home to Harlem and Kenneth Kaunda's Zambia Shall be Free
}

\author{
Mbanefo S. Ogene, PhD \\ Department of English Language and Literature, Nnamdi Azikiwe University, Awka \\ Esther Chikaodi Anyanwu, PhD \\ Department of English Language and Literature, Nnamdi Azikiwe University, Awka \\ Ngini Josephine Ojiaku, MA
}

Ugborikoko Secondary School, Effurun, Warri

\section{Doi:10.5901/mjss.2017.v8n3p343}

\begin{abstract}
One major problem confronting the definition of Comparative Literature is that of the involvement (on the one hand) of more than one literature under comparison and (on the other hand) that of the consideration of the multidimensional aspects of such literature, such as social, historical, linguistic, religious, economic and cultural aspects of divergent societies. This study is guided by the above factors in analyzing the concept of Racial Discrimination in Southern Africa and African American literatures in the sense that the former's experiences were on African soil, while the latter's were on the NewFound land (America). The paper observes that racial discrimination was much severe and oppressive without much resistance in America than in Southern Africa where Africans withstood and fought back against an unjust, wicked and oppressive system.
\end{abstract}

Keywords: Racial Discrimination, Power, Colonialism

\section{Introduction}

This study is based on the erroneous impression by some people that one race is superior to the other. Racial discrimination originates from the general notion that people are born in different geographical locations and genealogical origins and have close biological and cultural backgrounds and affiliations that are peculiar to and unite them as one people. It largely depends on the root word "race" which in this context means "a group of people who share the same language, history, culture, etc." (Hornby, 1194) According to Henslin (2006), race is a term that defines "a group of people with inherited physical characteristics that distinguish them from another group." (p.252)

Racial discrimination assumes its framework from the point where some races see themselves as better than the other and so discriminate against them. Hornby sees the term "discriminate" as a process of recognizing that "there is a difference between people or things; to show a difference between people or things... (or) to treat one person or group worse/better than another in an unfair way." (417) Another term for discrimination is to differentiate or distinguish. Racial discrimination has reached such a high dimension of interest that it is defined by the document of the International Convention on the Elimination of all forms of Racial Discrimination (ICERD) as

\section{Any distinction, exclusion, restriction or preference based on race, colour, descent, or national or ethnic origin which has the purpose of nullifying or impairing the recognition, enjoyment or exercise, on an equal footing, of human right and fundamental freedoms in the political, economic, social, cultural or any other field of public life (web)}

The negative aspects of racial discrimination has permeated the psyche of such races that consider themselves as superior and so regard their inferiors fit for slavery, oppression, abuse of power, violence and other forms of tyranny. These inhuman attitudes have influenced most writers in their literary expressions.

The interest of Europe in Africa started from European quest for exploration and exploitation of the continent. This quest wore the veneer of trade, religion and civilization as enshrined in the Charter of Berlin Conference of 1885. The result of this was the emergence of a strong and independent literature in English from Black Africa as an important post 
colonial development. Without taking cognizance of the indigenous culture, political structure and philosophy, the European colonizers exploited, with power and tyranny, the continent of Africa her citizens in the diaspora.

Power is "the ability to control people or things." (Hornby: 1136) It is further seen as, "political control of a country or an area or the right or authority of a person or group to do something." (Hornby: 1136) Mclean and Mcmillan see power as "the ability to make people (or things) do what they would not otherwise have done." (431) The general notion that power corrupts, and absolute power corrupts absolutely is a positive indication that any uncontrolled power leads to tyranny.

Tyranny is "a corrupt form in which a person ruled (others) in his own interest. Government by the will of the tyrant and arbitrary treatment of citizens, if not the systematic use of terror." (Mclean and Mcmillan: 547) Tyranny is synonymous with the colonial rule as the story of the colonial masters is replete with torture, violence, terror, and segregation or attitudes against the helpless slaves and colonies under their control. The major motivating factor behind the post colonial African state is the quest of the colonizer to gain total power in order to enforce obedience and compliance in a given social situation. Amidst this tussle for power is the claim of the paraphernalia of authority, which makes the tyrannies employed by the political class on power issues look constitutional and standardized.

\subsection{Keywords}

In the course of this study, the key words; Racial Discrimination, Power and Colonialism will often reflect interchangeably with Southern African and African American literature.

Racial Discrimination is an attitude of superiority by one race to the other as a result of having more power, language, culture, political and economic control and civilization than the other. This placed the weaker race in a disadvantaged position, thus compelling them to appear inferior and therefore deserve inhuman treatments, injustice and dehumanization.

Power is the ability to control others or compel them to do the wish of another. It is a political tool used by one nation to compel another, weaker one, to obey them and do their wish. Power is used in this sense to identify various means of control and oppression by Europeans over Africans, especially in those areas like Southern Africa and America where cases of racial discrimination were noted as a result of slavery and colonialism.

Colonialism is the system of adopting a policy for acquiring full or sometimes partial control over a country or continent by another with the aim of ruling them and exploiting their human and natural resources. It uses various means like religious indoctrination, military might, social, political and economic conquest. Force and coercion are mostly noted in this practice.

\section{Research Methodology}

The methodology used in this research is a comparative analysis approach based on data collected from the library. This approach maintains that scholars examine literature across national borders, time, periods, languages, genres, disciplines and boundaries. The study depends on both theory and relevant textbooks comprising fiction and autobiography from both African and African American writers. Other sources of data include journal publications and electronic devices.

\section{Research Aims and Objectives}

The research aims at examining the comparative literature as a field and also revalidating the authenticity of this branch of literature, especially on the aspect of themes and different contexts. This is presented in different regions of Africa, America and other parts of Europe. The objective is to further manifest that uniqueness of literature in contributing to another literature in different ways and manners and also in having some similarities.

\section{Background to Southern African Literature}

The Southern African region is an amalgamation of different nations like: Angola, Botswana, Lesotho, Malawi, Mozambique, Namibia, South Africa, Swaziland, Zambia and Zimbabwe. A greater part of the Southern African region was colonized by Britain, while Portugal colonized the rest. With such endowment of mineral resources like platinum, gold, iron, diamonds and cobalt, South Africa became the centre of attraction for other nations, especially the colonial masters. 
The years 1652, 1948 and 1994 were major remarkable years in the history of Southern Africa. The first Dutch colonists had settled at the Cape with the hope of establishing a half way station for the supply of provision to early farmers. This started a history characterized by conflicts with the indigenous people and later imperial Britain and other conflicts in 1948. Afrikaner nationalism found triumphant expression in the election victory of the National Party led by Dr. Malan.

The Afrikaner evolved the ideology of "apartheid" to consolidate that election victory and its nationalism. This term, "apartheid", is usually identified with the Dutch word. Roughly translated as "apartness" or "separateness", "apartheid" assumed an entirely new and enormous significance in Afrikaners, expressing an absolute distillation of racism and discrimination. Aimed at the furtherance of the interests of one group in a plural society, apartheid could hope to flourish only by a systematic marginalization of other interest groups. It therefore needed to evoke laws and practices to check rival nationalism, especially Black Nationalism. In this context, even though the black were overwhelmingly in the majority, Kruger's Land Act 1913 restricted them to only thirteen percent of the land; prevented by the education Act from acquiring a modern intellectual culture and by apprenticeship boards from having useful skills, they were still further hampered in the attempt to earn a living by job reservations...

Further measures by the colonizers in South Africa to enslave the people include the enactment of the 1950 Immorality Act which forbade all interracial sexual relations, even in marriage; the 1952 Abolition of Passes and Coordination of Documents Act, far from abolishing the pass law in reality, it gave it greater application, extending its scope to all Africans, even for the first time, women; the reservation of Separate Amenities Act, segregating against the black, reserved movie houses, beaches, swimming pools and post offices for Whites only; and the extension of the University Act did not extend the university education to the blacks but expelled most black students from the regular universities of south Africa, establishing for them a tribal college in which they could be educated in a Bantu language. In their efforts to ascertain the origin of discrimination, Banton and Herwood expressed the view which made scholars describe men as members of particular families, clans, tribes, distinguished by their language, dress and custom, a view which from the nineteenth century upheld the description that men belonged to races which differentiated them.

\section{Background to African American Literature}

African American literature is groomed in the experiences of black people who were originally taken as slaves into the United States of America. This literature is produced in the United States by writers who are of African descent. During most of the United States history, African Americans had claimed American identity but were not accepted as full citizens and were actively discriminated against. Because of the above factors the writing of African Americans were highly rooted in perpetual slavery, which were based on expression of pain and anguish. These writers had no other means of expressing their societal disdain and inhuman maltreatment by their white slave masters so their literature was based on whites against blacks; undue treatment given out against the blacks by their white counter parts.

The dominant style and form of the earliest black writing in the United States were the slave narrative with its overtones of active protest against an inhuman and tortuous system which suffused with their experiences in the institution of slavery in America. Their literature therefore differ with others that have aesthetic commitment as they have the aim of filling up the void created out of the pain and ache of the scars of chain, horse tail and iron whips, oppression, discrimination and other endless man's inhumanity to man that whet the hunger for freedom.

African American literature shares common traits with Southern African literature as it is often referred to as Dispersal literature due to its depiction of the terrible experiences of blacks scattered in the United States and in diaspora because of slavery. It is also regarded as Literature in Dispersal as it chronicles the suffering and nostalgic feeling of African slaves transported from one country to another countries or literature written outside the shores of Africa as they are cut off from their cultural heritage. These writers depicted elements of a new world of liberty where equality of blacks and whites will be quite possible and tolerated.

African American history is older than the emergence of the United States as an independent nation. Phillis Wheatley (1753 - 84) was the first African American to publish a book, as well as the first to achieve international reputation as a writer. Her book, Poems on Various Subjects was published in 1773. Wheatley was born in Senegal but was captured and sold into slavery at the age of seven. Other early African American authors were Jupiter Hammon (1711-1806), William Wells Brown (1814 - 1884) and Victor Sejour (1817 - 1874). Among the themes and issues explored in African American literature is: culture, racism and discrimination, slavery and equality, freedom, identity, revolt, ideologies, rejection and denial. 


\title{
6. Racial Discrimination in Kenneth Kaunda's Zambia Shall be Free
}

Kenneth Kaunda was born in 1924 at Lubwa in the hills of the watershed between the great Luangwa and Chambezi rivers. His father, David Kaunda, was the first African missionary to be sent by the Livingstonia Mission of Nyasaland in 1904 to the Bemba-speaking people of the Chinsali District of Northern Rhodesia. Kaunda advocated the philosophy of non-violence. He became a school teacher in his village missionary school at Lubwa. On 24 October 1964 Northern Rhodesia ceased to exist and the independent sovereign state of the republic of Zambia was founded under Kenneth Kaunda as its first President. Since then, Zambia has prospered under Dr. Kaunda's wise and firm control.

While narrating his experiences with the colonial masters, Kaunda (1962) reports the unfortunate policy of color bar. According to him,

In Mufulira, for the first time, I found myself suffering the indignities of the colour bar. Africans were not permitted to enter the European shops by the front door. If they wanted anything, they had to go to a hole in the wall at the side of the shop to ask for it. I determined to expose this system for what it was, an insult to my race and my people (p.31).

As a nationalist, Kaunda purposely flouted the laws that forbade the blacks to have free and open access to shops and chemist stores in their own land. Every human being has basic needs which include food, shelter and clothing. It is these needs that the Europeans (who are aliens) in African soil denied the black population or offered them under very humiliating situations. Kaunda singled out those shops that were notorious for demeaning Africans and flouted their rules. In one occasion, the girl behind the counter of the chemist shop motioned him to the chemist behind, who ordered him to 'get out of here'. (Kaunda: 32) Further demand on the girl to sell a book, from Kaunda, created more hostility as he states that:

\begin{abstract}
I would have to wait rather a long time, when two white miners in their overalls walked into the shop. Hearing the proprietor say again, 'Get out', they took me by the arms and frog-marched me to the door. There they were met by seventeen angry schoolboys who objected strongly to their schoolmaster being treated in this manner and they said so in no uncertain terms. A vigorous slanging match followed in which we were called 'black-skinned niggers' and we replied by asking what was so wonderful about a white skin any way. (32)
\end{abstract}

The worst is that the police did not take any action when the black were harassed and tortured, but they could afford to beat a black man who came to report a case to the police. The position of Kaunda as an elected member of the provincial counsel then notwithstanding, he was still addressed with disrespect. On an occasion when he was visiting Kitwe with Harry Nkumbula, President of the African National Congress in 1957, he was addressed as 'boy' by a young European girl of about seventeen years. This is as a result of the area being reserved to white and it has no African eating houses. According to Kaunda,

\begin{abstract}
When I told her that I was not a 'boy' and all I wanted was a dozen sandwiches, she spoke to an elderly white woman who was apparently in charge. On asking me what I wanted, she repeated that 'boys' were not served at that counter. I repeated in my turn that I was not a 'boy'. At this point I was dragged out of the café by my clothes by a European man who had already dragged Harry Nkumbula outside the café. This white man hit Harry and called him a cheap, spoiled nigger. Five other white men joined him in attacking us and we defended ourselves. White men and black men passing joined in the fight, and an apartheid type of brawl took place. This was my third and last fight. (p.34)
\end{abstract}

What informed the behavior of the characters above was the feeling of race superiority to the other. The European lacked respect and regard for Africans even to the point of humiliating and insulting an elderly political leader like Kaunda as the young girl of seventeen exemplified.

Not minding the denigration, the oppressive nature of the "white" men caused them to hit the blacks with reckless abandon, thereby causing a public fight. When this matter was reported to the police, the police officer "called Harry to a room and closed the door and beat him up." (34) Even at the court, blacks were not given their right to be medically examined by a doctor, so Kaunda chose not to continue the case. When nine African workers staged a protest for the beating of their leaders, the police guard on the café arrested the leader of the group and fined them.

The situation of Southern Africa was such that even with the passing of the anti-color bar legislation by the Northern Rhodesian government, the law was flouted. This also affected Christians as an incident that occurred in March 1962 was repeated. The Vice-President of the Christian Council of Northern Rhodesia, the Rev. M.S. Lucheya, entered a café with his European colleague and the President of the council, and was refused a cup of tea. This show of shame by racism cuts across every strata of the African society. This caused Africans bitterness against the European settlers who treat them like subhuman species in their own land of birth. 


\section{Racial Discrimination in Claude McKay's Home to Harlem}

Black writing in America started as the Black experienced the institution of slavery. The major style and form of much of the earliest Black writing were the slave narrative with its overtones of active protest against the inhuman and tortuous system of the slave owners. To the African American literary exponents, 'literature' could not be an abstract art practiced for art's sake and beauty's reward, but a means to fill up the void that grew out of the ache and pain of the whip's lash, the chain's scar, and the endless hunger for freedom. After many years of existence in America, the black who had traced their history to these years were not accepted as the citizenship of the country, but were discriminated against. Their writings were therefore perpetually rooted in slavery, expressing pain and anguish. While the slaves found themselves working in plantations, doing household chores, serving others were brutally tortured, oppressed and raped. They were not allowed to get married and were also sold to the higher bidder. With all the disadvantages imposed on the blacks, the white still found a way of maintaining their supremacy and superiority over them. One of the measures used by the whites was the invocation of Jim Crow laws which were largely enforced by the Ku Klux Klan.

\section{The Jim Crow Law and Racial Segregation}

This law was the name of the racial segregation which operated primarily but not exclusively in Southern America. It was more than a series of rigid anti-black laws which empowered the white to relegate the blacks to the background and treat them without any respect for human dignity. The law gave even Christians the impetus to teach that 'Whites' were the chosen people, while the 'Blacks' were cursed to be servants and that God supported racial segregation.

On the part of education, the law upheld that 'Blacks' were innately intellectually and culturally inferior to the whites. Blacks were excluded from public transport and facilities, juries, jobs and neighborhood. It was illegal for Blacks to sit in coach seats reserved for whites and whites could not sit in the coach seats reserved for Blacks. These laws were pasted on all corners of America to remind the Blacks of their place in the society.

\section{Claude McKay's Home to Harlem and Racial Discrimination}

Claude McKay happened to be one of the early African American writers that started the cause of Harlem renaissance. He really contributed to the moves by blacks to use affirmation of black consciousness as a useful tool to awaken the oppressed and exploited black race to believe in their culture, search for self identity and stand on equal footing with other people of the world. His strong commitment to black consciousness led McKay to be very concerned with the culture of the black diaspora. He was very conscious of the importance of racial consciousness on the part of the black people to help them survive in the western world. To McKay, if the blacks must liberate themselves from the yoke of slavery and dependence, they would have to pursue their own cultural roots and conventions so as to assert their own identity. The attitude of some blacks who could not embrace their identities but rather sought solace in the European culture dissatisfied him.

McKay's Home to Harlem depicts two characters, Jake and Ray. While Ray is an intellectual who refuses to identify himself with black culture so that he has to take flight to Europe at the end of the novel, Jake is depicted as bold and active enough to hate and love and incapable of action due to inadequate knowledge from his college education. Jake Brown is McKay's projection of ideal image of the black; he embodies resourcefulness of the black, instinct, spontaneity, optimism and independence. Jake's yeaning to go back to his homeland is so strong that he is willing to take the arduous work of a stoker in a freighter: "Roll on, Mister Ship and Stinks all the way as you roll. Jest take me "long to Harlem is all I pray. I'm crazy to see again the brown skin chippies "long Lenox Avenue. Oh boy!" (McKay 3). Jake joins the army innocently to fight against German invaders for the cause of freedom, but is disappointed because even in the army, there is discrimination against the black. Instead of sending him to fight, he is relegated to tedious manual work. He therefore decides to desert the army, claiming that he will have nothing to do with the conflict of the white economic and political imperialism. He reflects on this while going home saying, "Why did I ever enlist and come over here?" he asked himself. "Why did I mix mahself up in a white folks war? It aint ever was any of black folks' affair. Niggers em evah always such fools, anyhow. Always thinking they've got something to do with white folks business."

Jake strongly feels the stigma and bitterness of discriminations inflicted on the blacks during the World War. He is resentful over the way the Yankees address the blacks as 'darky' or 'niggers'. According to McKay,

He knew that when a Yankee said Nigger, he meant hatred for the Negroes, whereas when he said 'darky', he meant friendly contempt. He preferred white folks' hatred to their friendly contempt. To feel their hatred made him strong and 
aggressive, while their friendly contempt made him ridiculously angry, even against his own will (133)

Beating and lynching of blacks by whites at the slightest provocation was a constant occurrence. There was segregation and discrimination against the blacks by the whites, this continued after the great declaration. According to W.E.B. Du Bois (1903),

\begin{abstract}
A black stranger in a Baker Country, Georgia, for instance, is liable to be stopped anywhere on the public highway and made to state his business to the satisfaction of any white interrogator. If he fails to give a suitable answer, or seem too independent or 'sassy', he may be arrested or summarily driven away. (p. 133).
\end{abstract}

This hatred is equally noted in Richard Wrights' Native Son where the muggers filled with loathsome dislike for the blacks, exhibit terror. Wright states that, 'being dragged over the snow, his feet were up in the air, grasped by strong hands. 'Kill 'im!' 'Lynch 'im!' 'That black son of a bitch!' 'Kill black ape!' (301) The situation in America is such that blacks feel that it is right to accept anything thrown at them by the whites.

\title{
10. A Comparative Analysis of McKay's Home to Harlem and Kaunda's Zambia shall be Free
}

Comparing the two texts and contexts under study, it was observed that African American literature shared common traits with Southern African literature as it is often referred to as Dispersal literature due to its depiction of the terrible experiences of blacks scattered in the United States and in diaspora because of slavery. Both authors, Kenneth Kaunda and Claude McKay depicted elements of a new world of liberty where equality of blacks and whites will be quite possible and tolerated.

\subsection{Discrimination}

There are strong cases of segregation in the two books being studied. While Kaunda's experiences of segregation is summed up in the acronym "colour bar", that of McKay is on stigma and resentment against blacks. While narrating his experiences with the colonial masters, Kaunda states that, "Africans were not permitted to enter the European shops by the front door. If they wanted anything, they had to go to a hole in the wall at the side of the shop to ask for it." (31) To McKay's protagonist, Jake, there is the feeling of the stigma and bitterness of discrimination inflicted on the blacks during the World War, and he is resentful over the way the 'whites' refer to the blacks as 'darky' or 'niggers'. To him, when a yankee said Nigger, he meant hatred for the Negroes; whereas when he said 'darky', he meant friendly contempt.

\subsection{Slavery}

Whichever way the matter under study is looked at, there is a strong case of slavery reflecting in the two books. Slavery is not so much noticed in Kaunda's Zambia Shall be Free but it is the major theme in most African American literature and also in McKay's Home to Harlem. To McKay, if the blacks must liberate themselves from the yoke of slavery and dependence, they would have to pursue their own cultural roots and conventions so as to assert their own identity. There is also the case of oppression against blacks, in both books and this result to conflicts.

The peculiarities of the two works under study are that Kaunda's Zambia Shall be Free is largely concerned with nationalistic consciousness and struggle for freedom, while McKay's novel is preoccupied with torture, rape and struggle for freedom on the part of the blacks.

\section{Conclusion}

Racial Discrimination in Southern African literature and African American literature has many similarities but differs in the sense that the Southern Africans were more resistant and bold to fight against racism coated under 'apartheid' law, while the African Americans were less aggressive and suffered the identity problem more due to the dominating number of the whites in American setting and also due to many years of exposure to oppression, torture and subjugation. They (blacks) therefore at a stage accepted their helpless situation until the move to liberate them by the activists.

\section{References}

Du Bois, W.E.B. (1903). The Souls of Black Folk. Atlanta. 
Heslin, J. (2006). Sociology: A Down-to-Earth Approach. Boston Allyn and Bacon, 2006.

Hornby, A.S. (2005). Oxford Advanced Learner's Dictionary of Current English, International Student's Edition. Oxford: Oxford University Press, Seventh Edition, 2005.

International Convention on the Elimination of all Forms of Racial Discrimination, G.A. Res 2016 (1965), United Nations Treaty Collection (1969).

Kaunda, K. (1962). Zambia Shall be Free An Autobiography. London: Heinemann Educational Books.

Mckay, C. (1928). Home to Harlem. New York: Harper.

Mclean, L., \& Alistar, M. (2003) Oxford Concise Dictionary of Politics. New York: University Press.

Wright, R. (1940) Native Son. New York: Harper. 
ISSN 2039-2117 (online)

ISSN 2039-9340 (print)
Mediterranean Journal of Social Sciences MCSER Publishing, Rome-Italy
Vol 8 No 3

May 2017 